\title{
COMPETING FOR THE EMPEROR: GAMES AND FESTIVALS IN HONOUR OF HADRIAN* \\ COMPETIR POR EL EMPERADOR: \\ JUEGOS Y FIESTAS EN HONOR DE ADRIANO
}

Rocío Gordillo Hervás

Universidad Pablo de Olavide, Sevilla RGORHER@UPO.ES

\section{RESUMEN}

This article analyzes the agonistic events that were held in honour of the emperor Hadrian by the cities of East Mediterranean during the first two centuries $\mathrm{AD}$, with a special focus on the

\section{Abstract}

Este artículo analiza los eventos agonísticos organizados en honor del emperador Adriano en las ciudades orientales del Mediterráneo durante la primera mitad del siglo II d.C. viendo su función

* This article has been researched with in the project Adriano y la integración de la diversidad regional. Una perspectiva histórica e historiográfica (HAR2015-65451-c2-1 MINECO/FEDER) of the University Pablo de Olavide. 
city-elites' attempt to obtain the emperor's favour by means of these games. In the first part of the article, the cities that organized these agones are classified according to four categories: 1) cities that introduced agonistic contests dedicated to the emperor within their traditional agones; 2) cities that organized games ex novo and presumably celebrated them on a single occasion; 3 ) cities that organized games ex novo and made them permanent events; 4) cities whose games, which were created ex novo, are included in the new Hadrianean calendar. This classification will allow, in the second part of the article, to underline both the degree of closeness between Hadrian and the various city-elites and the special status acquired by those cities whose agones were included in Hadrian's nea periodos. uno de los elementos de los que se servían las élites cívicas para captar la atención del emperador. En la primera parte del artículo, las ciudades que llevaron a cabo estos agones se clasifican en torno a cuatro cateogrías: 1) ciudades que introdujeron disciplinas agonísticas dedicadas al emperador en sus sus juegos tradicionales; 2) ciudades con fiestas ex novo que se realizaron presumiblemente una única vez; 3) ciudades cuyos juegos ex novo perduraron a lo largo de los siglos; 4) ciudades cuyos juegos ex novo fueron incluidos en el nuevo calendario adrianeo. Esta clarificación permitirá desarrollar en la segunda parte del artículo el grado de aproximación de las élites cívicas con el emperador Adriano, así como el status que adquirieron las ciudades cuyos juegos fueron incluidos en la nea periodos adrianea.

\section{Palabras Clave}

Hadrianeia, Greek athletics, euergesia, civic elites, imperial cult

\section{KEY WORDS}

Hadrianeia, juegos atléticos, evergesía, élites cívicas, culto imperial 
"The Agonistic Festival was a DEFINING CHARACTERISTiC of Greek civic life under Roman rule": ${ }^{1}$ with these words O. van Nijf emphasizes the role played by sports within Greek paideia during Roman times. The imperial creation of agones in Nicopolis, Rome and probably Neapolis, the opening of gymnasia, and the publication of works such as the Gymnasticus by Philostratus, represent some of the milestones that underlined the growing importance of sport in the Roman world. The attraction exerted by athletic contests onto the population did not go unnoticed to the emperors, who took steps towards their use to further the integration of the imperial provinces and to further spread the imperial cult. ${ }^{2}$ Already since Augustus' times, and with a considerable increase during Hadrian's rule, newly-founded games began to be named after the reigning emperor, such as the Augusteia, Tiberieia, Claudieia, Vespasianeia or Traianeia. On the other hand, the agones became also an instrument for the various cities to attract the attention of the emperors by organizing games dedicated to them, thus renewing their allegiance to Rome.

This article consists of two parts. The first part will provide a classification of the cities that organize agones in honour of Hadrian according to whether they introduced the imperial cult into the traditional city-agones or they founded Hadrianean games ex novo. The second part of the article will focus on two main points, namely the crucial role played by the city-elites in spreading the imperial cult by means of the agonistic games, and the reasons why Hadrian rewarded the cities of Ephesus, Smyrna and Athens by including their Hadrianean games in the nea periodos of Alexandria Troas.

1. Van Nijf, 1999, p. 198.

2. Albanidis and Giatsis, 2007, pp. 196-197; Van Nijf and Williamson, 2015, pp. 95-112. 


\section{Hadrian Games}

The organization of an agon in Roman imperial times usually revolved around two main pivots, the emperor and the city-elites. Before starting the process, it was necessary for the organizing city to obtain permission for holding the games from the emperor. Among the various emperors, one of the major promoters of athletic contests was certainly Hadrian. He appeared as the euergetes of the celebrations of two major cities in Greece: specifically, as agonothetes of the Dionysian Games of Athens in 124/125 AD and as patronomos of Sparta, a position which appointed him as the "guardian of tradition" and "protector of the traditions of Lycurgus". ${ }^{3}$ Under Hadrian's rule there was a true explosion of agonistic events, with up to twenty-one new games dedicated to the emperor being held according to M.T. Boatwright. ${ }^{4}$ Being the host of imperial games was a privilege and a honour for the cities, and agones became thus an important instrument for competition for prestige among cities. An example of this kind of competition can be seen within games founded in honour of the emperor by the Cilician cities of Anazarbus and Tarsus, in what is seen by A.H.M. Jones as contest for supremacy over neighbouring cities: "Tarsus celebrating the Epinicia, Olympia, Actia, Coraea, Demetria, as well as various games in honour of different emperors, Augusteia, Hadrianeia, Commodeia, Severeia (...) Anazarbus responding with a rival Epinicia and Olympia, the Sebastia, ecumenical games in honour of Hadrian and Decius, and the Antoniniana, first of the world". 5

The games in honour of the emperor represented a mean for the competition not only between the various cities, but also between the city-elites of the same city. ${ }^{6}$ The games were a symbol of the identity of the city-elites, who were in charge of the administration and performance of the agones and on some occasions had to finance the games with their own money. In charge of the organization of each of the games was an agonothetes (president of games), who is usually mentioned in the inscriptions. As will be discussed later on, some of the agonothetes themselves referred to the "Hadrianean games" which they had organized as megala, thus trying to elevate them above the games held by other agonothetes, for which no similar qualification is provided. Once the emperor had approved the organization of the games, the cities were

3. On the position of patronomos: IG V.1, 32b; see Bradford, 1977, p. 494. There is some scholarly disagreement over the dating of Hadrian's position as patronomos: in 128-129 AD according to Kennell, 1991, p. 131; in 127/128 AD according to Bradford, 1986, pp. 71-74; Cartledge and Spawforth, 2002, p. 108; in $128 \mathrm{AD}$ according to Weber, 1907, p. 211; in 123/124 AD according to Atkinson, 1949, p. 465.

4. Boatwright, 2000, p. 99. In general see: Lämmer, 1967; Le Glay, 1976; Leschor, 1998, n. 10.

5. Jones, 1998, p. 208.

6. Van Nijf, 2004, p. 221; Pleket, 2010, pp. 175-203. 
fully engaged in the search for funding to cover the costs, ${ }^{7}$ such as the construction or restoration of recreational areas (mainly stadiums and theatres), the remuneration of the athletes and the technitai who would win the various contests, sacrifices, banquets, and even the oil supply for the gymnasia. F. Camia analyzed the sources which were available to the cities in order to fund their agonistic competitions, ${ }^{8}$ both by means of public funding which was set aside by both the city and the sanctuary, and thanks to the euergetism of the city-elites. The best known case of costs being covered through euergesiai is a decree in Oinoanda (Lycia), where the Emperor Hadrian authorized the organization of the Demostheneia games, which were dedicated to Hadrian himself, and which had the entire funding covered by C. Iulius Demosthenes. ${ }^{9}$ Demosthenes himself makes a detailed summary of the various expenses for the games, specifying the cost of each contest.

\subsection{Traditional Games of the Greek Cities}

The first group of cities that will be analyzed in this article consists of those that introduced the imperial cult in their own traditional festivals. This method is the simplest of all since the only changes are made to the titulature of the agones by adding to it the name of the emperor, and by the introduction within the contests of additional disciplines in honour of the emperor. An significant example is provided by the city of Thespiae (Boeotia) and its Shrine of the Muses, where the penteteric agones Mouseia ${ }^{10}$ were held since the second half of the third century BC. At the beginning of the century Thespiae carried out a reorganization of its games in order to attract a larger number of participants and increase the importance of the games beyond the city's boundaries. Following the example of the Pythian games, artistic contests were introduced in the Mouseia games, which gained thus the qualification of isopythian. The association of these games with the imperial cult began in the first century AD, ${ }^{11}$ although the emperor's name would not be introduced in the titulature until the

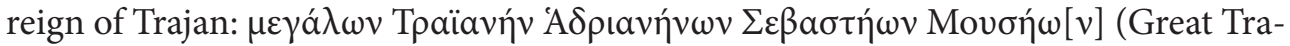
janean Hadrianean Augustan Musean Games). ${ }^{12}$ The increasing popularity of the Mouseia had them lasting until the reign of Caracalla in the third century AD. Some

7. Zuiderhoek, 2009, pp. 76-88.

8. Camia, 2011.

9. SEG 38, 1462; Wörrle, 1988; Mitchell, 1990.

10. Hom., Il. XIII 21; Ath., 14 629a; Plut., Amat. 1; Paus., IX 31, 3.

11. Schachter, 1981-1994, p. 152.

12. I.Thesp. IV 177. 
athletic inscriptions provide useful information on the different disciplines that were included, such as comedies, tragedies, and competitions of heralds and citharists. Together with these competitions, there were also two contests entirely dedicated to the

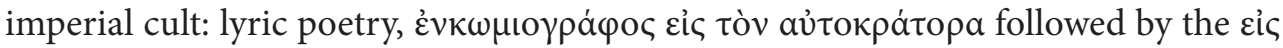

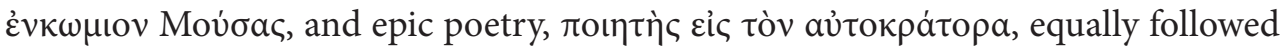

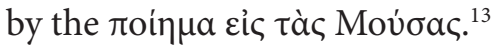

This same process took place in the city of Xanthos (Lycia). The inscriptions mention the Letoa Traianeia Hadrianeia Antoneia games, whose name merges the traditional celebrations that took place in the sanctuary of Letoa with the name of the emperors Trajan, Hadrian and Antoninus Pius. ${ }^{14}$ The only additional hypothesis about the games is formulated by P. Baker and G. Theriault, who consider it likely that these agones were related to the Lydian Koinon, given the occurrence of the expression $\pi \alpha \rho a ̀$ $\Xi a v \theta$ ío $<\mathrm{l}>\varsigma$ in the inscriptions that refer to the games. ${ }^{15}$

A different case is that of the Hadrianeia Heracleia Isaktion agones in the city of Heraclea in Pontus. ${ }^{16}$ The lack of epigraphic documentation does not allow to shed light on the exact time when the games were founded, and the scholarship is split between two hypotheses concerning their origins: either that the games were the result of the merging, during Hadrian's times, of the Heracleia agones in honour of the mythical founder of the city with the imperial cult, as possibly shown by their adoption of Hadrian's name; or that they were founded ex novo during the reign of Hadrian. ${ }^{17}$ The first hypothesis implies that the games were founded under the reign of Trajan. In one of Pliny's letters, he writes to Trajan to consult him on the inheritance of Julius Anchus. In the will of this citizen, born in Pontus, a sum of money was donated to the cities of Heraclea and Tium, with Pliny being in charge of deciding whether the money should be used for the embellishment of the cities or for the foundation of some penteteric

13. Schachter, 1981-1994, pp. 177-178.

14. Courtils, 2002, p. 304; Baker and Thériault, 2014, p. 100.

15. Games dedicated to "ancestral gods" were traditionally held in Xanthos/Xánthi, and included those in honour of Leto, Artemis and Apollo, which were still held during imperial times. Augustus introduces the Romaia, an agon in honour of the Roman emperor. On the Letoa see IGR III, $605=$ TAM II.1, 496; Baker and Thériault, 2014, p. 107; Hansen and Le Roy, 2012. On the Romaia Wörrle, 1988, p. 238.

16. MAMA VIII 521.

17. Magie, 1950, p. 1472, n. 10. As the name of the games suggests, the organization probably followed the same pattern of the Actian games instituted by Augustus in Nicopolis after the battle of Actium: Suet. Aug. 18, 2; Paus. V 23, 3; X 2, 2 and X 38, 4; Cass. Dio LI 2-3. On the evidence of Actian games: Moretti, 1953, $\mathrm{nn}^{\circ} 58,62,67,68,69,70,71,75,77,78,79,89,81,82,85,87,88,90$. On the great Actian games see id., nno 59, 60. On general topic see Pavlogiannis et alii, 2009, pp. 79-102. 
games that would bear the name of Trajan. Accepting the first hypothesis (i.e., that the games were founded during Trajan's rule) would entail that Pliny eventually chose the second option resulting in the organization of the games Traianea Heracleia, ${ }^{18}$ which in Hadrian's times acquired the name of Hadrianeia. I would be more inclined towards the second hypothesis, which postulates that the games were founded during the reign of Hadrian. In the inscriptions of the athletes who took part in the Hadrianean games of Xanthos and Thespiae, which are dated after the death of Emperor Hadrian, the games are still referred to as "Trajanean and Hadrianean", that is, they do not lose the name of the previous emperors. In the case of Thespiae, the insertion of the name of Antoninus Pius does not replace those of the previous emperors, and the games' titulature becomes Letoa Traianeia Hadrianeia Antoneia. In the case of Heracleia, the only mention of the Hadrianeia comes from the inscription of the athlete M. Aurelius, dating from the early third century AD. If these games had been those funded with Julius Anchus' money, their name would have not shown Hadrian's name replacing that of Trajan. If in the third century AD these games are still being calling only by the name of Hadrian, it would imply that they were founded ex novo under the reign of the emperor, as in other cities.

\subsection{Agones Ex Novo}

The second group of cities to be analyzed consists of those that founded agones ex novo and, as far as the epigraphic evidence goes, celebrated them on a single occasion. As rightly stated by $\mathrm{M}$. Boatwright, it is possible that the main cause of this sudden increase in the number of games was due to extraordinary celebrations for the emperor's visits. One of the most important facets of Emperor Hadrian was his desire to travel and visit in person the territory he ruled upon. Several scholars have tried to trace the routes followed by the emperor on his travels. In the case of the eastern Mediterranean, Hadrian made two big journeys, the first during the years 123$124 \mathrm{AD}$ and the second around $128-132 \mathrm{AD} \cdot{ }^{19}$ It is very likely that the city-elites took advantage of the occasion to organize all kinds of celebrations, not just to honour the emperor but also to have the opportunity to approach him directly. Concerning the first journey, there is evidence of the celebrations funded by Antonia Tyrannis of Erytea, the Megala Hadrianeia Epibateria which, as its name suggests, comme-

18. Plin., Ep. X 75-76.

19. Weber, 1907; Syme, 1988; Højte, 2000; Birley, 2004.

ARYS, 16, 2018 [177-205] ISSN 1575-166x 
morated Hadrian's visit to the island. ${ }^{20}$ Among the games that commemorated the visit of the emperor are the Hadrianeia Olympia in $124 \mathrm{AD}$ in Thyateira, ${ }^{21}$ and the Hadrianeia in Coela. ${ }^{22}$ During Hadrian's second journey to the eastern empire the Olympia of Tralles were organized in $129 \mathrm{AD}^{23}$ and the panegiris of Gaza in 130 AD. ${ }^{24}$ The Hadrianeia ${ }^{25}$ of the city of Attuda in Caria, the founding date of which remains unknown, were likely connected to the visit of Emperor Hadrian, as well as the Hadrianeia Antinoeia of Bithynia-Claudipolis, ${ }^{26}$ the Hadrianeia of Magnesia ad Sipylum ${ }^{27}$ and possibly the agones of the city of Sardis. ${ }^{28}$

In some cases, cities organized agones to honour the Emperor Hadrian not just for a single occasion, but on a regular basis. The Hadrianeia or Hadriana Olympia of Anazarbus were founded in order to commemorate one of the two visits of the em-

20. IGR IV 1542; Halfmann, 1996, p. 112; Haensch, 2009, p. 96.

21. IG II, 3491; Petzl, 1974, pp. 117-119; I.Smyrna 668; IGR IV 1260; SNGD 688. There are few references to the interaction between Hadrian and Thyateira. We only know that Hadrian granted the city some benefits, and that the city because of this erected to him altars with the titles "Soter" and "Ktistes": Robert and Robert, 1978, p. 452; TAM V.2, 310; IG II², 1088; SEG 41, 67; IGR IV 1196-1199.

22. T-TEA, 179-180. On the relationship between Hadrian and the city of Coela see Grelle, 1972, p. 180; Albanidis and Giatsis, 2007, pp. 177-197.

23. I.Tral 136; IG II², 3163; FD III.4, 476; SEG 52, 1448; SEG 34, 1120; I.Ilion 125, pl. 21; I.Tral 119; TAM V.2, 1022; Magie, 1950, p. 1480, n. 33. The emperor might have visited Tralles due to the impulse of Phlegon, who was one of the emperor's liberti and who was born in Tralles: Weber, 1907, pp. 222223; Boatwright, 2000, p. 101. Magie, 1950, p. 1480, n. 33 and Birley 1997, p. 222 place the date of the emperor's visit in 129 AD. According to Halfmann, 1996, pp. 138-140, the visit took place in 124 AD. The relationship between Hadrian and the city of Tralles dates back to $127 \mathrm{AD}$, when the emperor granted to the city, through the intermediation of Fabricius Priscianus Charmosynus, the distribution of a great quantity of grain imported from Egypt: CIG 2927. The city erected a statue in Hadrian's honour and proclaims him Soter and Ktistes: CIL III 444.

24. Chron. Pasch. I 474. In favour of the Hadrianeia: Moretti, 1953, p. 210; Lämmer, 1967, p. 39; Leschor, 1998, p. 44, n. 40; Boatwright, 2000, p. 101; Weiss, 2014, pp. 180 and 182. Against: Wallner, 2001.

25. CIG 3952. The Olympia Heracleia Adrasteia also were held in this city: MAMA VI 79 and 81, 82; Mitchell, 1993, p. 225, n. 197.

26. MAMA VIII 521. During the emperor's journey to Bithynia around 123-124 AD he visited the cities of Nicomedia, which adopted the title of Hadriane, Nicea, to which Hadrian very likely grants its first neokoria, and Bithynium-Claudiopolis: Birley, 1997, p. 158; Burrell, 2004, pp. 163-164. The Hadrianeia Antinoeia were obviously dedicated to Hadrian and Antinous, the latter having been born in the city of Bithynium-Claudiopolis (Cass. Dio LXIX 11, 2; Paus. VIII 9, 7)

27. The games in honour of Hadrian in the city of Magnesia are only known from a single coin, by the dating of which it can be surmised that at the end of the 3rd century AD celebrations in honour of Hadrian, Alexander, Antoninus and the agon Enmonideia were held in Magnesia: SNGD 1968, 278.

28. Le Glay, 1976, p. 361.

ARYS, 16, 2018 [177-205] ISSN 1575-166x 
peror, either in 117-118 AD or $131 \mathrm{AD} .{ }^{29}$ Some athletic inscriptions reveal the sacred, ecumenical and iselastic character of the celebrations, and that they were held until

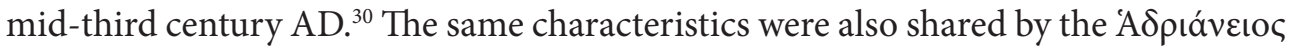
$\Phi \iota \lambda \alpha \varepsilon ́ \lambda \varphi \varepsilon ı \varsigma$ of Alexandria ${ }^{31}$ or the Hadrianeia or Hadriana of Antioch in Syria. These last games appear in the athletic inscriptions from the late second century AD to the first half of the third century $\mathrm{AD} .^{32}$ It is likely that the scarcity of epigraphic documentation during Antoninian times is due to Marcus Aurelius' prohibition for Antioch to organize any kind of spectacles, because of the support provided by the city to Avidius Cassius. ${ }^{33}$ The Hadrianeia of Antioch appear in the Chronicle of John Malalas, who states that on June 23, the city held a festival named after Hadrian which was instituted on the occasion of the inauguration in Daphne of the buildings funded by the emperor. ${ }^{34}$ Unfortunately John Malalas does not specify the year when this event took place, although the dates of the emperor's visits in 123 AD and 129$130 \mathrm{AD}$ are the most likely options. In his study on the itineraries followed by the emperor in his eastern journey W. Weber states that the celebrations ought to have taken place in the year $129 \mathrm{AD}$, since the route followed by Hadrian during his first trip would exclude his presence in Antioch in June of the same year. ${ }^{35}$

Epigraphic evidence suggests other reasons behind the founding of games in honour of Hadrian. In some cases the occasion for celebrating was not the emperor's visit, but the concessions and benefits that the emperor had granted to the city. The Hadrianeia games or Hadriania Olympia in the city of Tarsus, which according to existing evidence were held during the second half of the third century $\mathrm{AD},{ }^{36}$ probably owed their foundation to the city obtaining its first neokoria. The first mention of the neokoria of Tarsus is found on a Hadrianic coin. The obverse of the coin carries

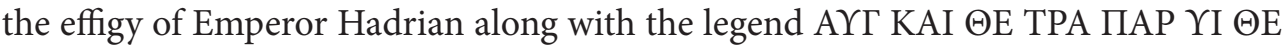
NEP YI TPAIA A $\triangle$ PIANOC CE ПП. On the reverse there is the ten-column porch of a temple with $A \triangle P I A N \Omega N$ TAPCE $\Omega N$ MHTPOПO $\Lambda$ E $\Omega$ C KOINO KI $\Lambda$ IKIAC on the architrave. As indicated by B. Burrell, the inscription of the coin's reverse

29. Halfmann, 1996, pp. 190, 194; Birley, 1997, p. 69; Ziegler, 1993, pp. 22-23.

30. I.Anazarbus 25; FD III.1, 555; Ziegler, 1985, p. 32, B1; id. (n.32) 419, 428, 431, 612.

31. Probably funded around 130-131 AD: I.Sardis VII 79. The epithet Philadelphius might refer to the emperor's fondness for his sister Paulina: Birley, 1997, p. 257.

32. I.Tral 117; FD III.1, 550; I.Side 149; I.Anazarbus 25; FD III.1, 555.

33. HA, Av. Cas. 9, 1.

34. Malalas, Chron. XI 278, 16.

35. Weber, 1907, pp. 121, 131; Downey, 1961, pp. 222-223; Boatwright, 2000, p. 99, n.75.

36. SNGS I, 1139, 1185; SNG IV, 5348; SNGD 6077. 
could be related to the imperial cult in the city and thus to the neokoria granted by Emperor Hadrian. ${ }^{37}$ This coin would thus establish a post quem indicator of the year in which Tarsus obtains the neokoria. Emperor Hadrian is referred to as $P($ ater $) P(a$ triae), a title he assumes in $128 \mathrm{AD}$, so the concession ought to have been granted after this date. It is likely that due to the introduction of the new imperial cult and the granting of the neokoria, the city of Tarsus celebrated Hadrian also by adopting the appellative of $A \delta \rho \iota v \eta^{38}$ and instituting regular celebrations, the Hadrianeia games, to commemorate the fact.

The Cyzicus games in Mysia could also be linked to the imperial concession of a neokoria. ${ }^{39}$ In epigraphic sources these agones appear under three different denominations, Hadriana Olympia, Hadrianeia and Olympia. ${ }^{40}$ In two inscriptions we find the denomination Hadrianeia Olympia Koinon Asias, and while F.W. Hasluck sees it as a reference to a single agon founded in $139 \mathrm{AD},{ }^{41} \mathrm{~L}$. Moretti considers the Hadrianeia Olympia and the Koinon Asias as two separate games, with the latter being founded in $139 \mathrm{AD} .{ }^{42}$ The athletic inscriptions shed no light on when they were held for the first time. The only kind of dating can be inferred from the mention of the athlete Callimorophus, whose victories took place during the reign of Emperor Hadrian, that is, between 117-138 AD.

Alongside the city-elites, the synod of technitai was also in charge of the organization of some of the imperial agones. There is evidence of the creation of a new type of agonistic games in Hadrian's times, the mystikos agon, in the cities of Ankara, Iconium and Side, games that were held until half of the third century AD. ${ }^{43}$ These celebrations were organized by the synod of the technitai and were dedicated to Dionysus, the synod's patron deity, and to the Emperor Hadrian as New Dionysus. They were probably religious celebrations that were part of the mysteries associated with the imperial cult, which included dramatic-religious stage events and ritual dancing that were held in the theatre. ${ }^{44}$ In an inscription dated to the 3 rd December of $128 \mathrm{AD}$, the "world-wide performers (technitai) gathered around Dionysos and

37. Burrell, 2004, pp. 212-213.

38. BMC Cilicia $187, \mathrm{n}^{\circ} 150$ y 151.

39. Burrell, 2004, pp. 86-94, 337.

40. I.Tral 135; CIG 2810, 3428, 3672; IG II-III, 3169/70; BE 1970, 16; IGR IV 16, 154, 162; IG XIV 972;

EA 1990, 34-36 = SEG 40, 1141; IGBulg III.1, 892; Bodnar and Mitchell, 1976, p. 26, nº 1 .

41. Hasluck, 1910, pp. 187 and 260.

42. Moretti, 1953, p. 283, n 3 and 286, no 1 .

43. Robert, 1960, pp. 367-368.

44. Pleket, 1965, p. 336.

ARYS, 16, 2018 [177-205] ISSN 1575-166x 
emperor Trajan Hadrian Augustus Caesar, new Dionysos, namely, those who are crowned sacred victors, fellow-contestants, and registered members of the sacred theatrical synod (or: as well as the members of the sacred theatrical synod)" ${ }^{25} \mathrm{a}$ decree signed by the emperor Hadrian and Trebius Sergianus ${ }^{46}$ celebrates Ulpius Aelius Pompeianus, high priest of the koinon of Galatia and Helladarcha, for his euergesia within the organization of the first mystikos agon of Ankara. ${ }^{47}$ According to the decree, the city council chose Ulpius Aelius Pompeianus ${ }^{48}$ as agonothetes of the games after having received the approval of the Emperor Hadrian. The former carried out the agonothetia exceptionally well and with unusual speed, and he even made effort to intercept the contestants who were on their way to other games in order to invite them to the mystikos agon. He also organized the games flawlessly and with great splendour, without skimping on costs, and paid from his own pocket for the prizes of the winners of the various contests. On line 21, the inscription refers to the work of Pompeianus in the organization of the mysteries, likely those related to the imperial cult, and thanks to him, the city succeeded in proclaiming its devotion to the two deities to whom the games were dedicated, Dionysus and the emperor Hadrian as New Dionysus.

In the same stele it is stated that the synod decided to reward Ulpius Aelius Pompeianus for his euergesia with the erection of two statues with his likeness, one of which to be located in the theatre of the city of Ankara to "be an example of virtue to the spectators" to the competitions and which should be honoured by the participants in mystikos agon with crowns, under penalty of expulsion from the contests. Archaeological excavations have revealed three bases of statues dedicated to Ulpius Aelius Pompeianus in Ankara, where he was honoured as Euergetes, Helladarcha and high priest, and it is likely that one of them is the one that was erected by the synod for Pompeianus' euergetic activity. ${ }^{49}$ The second statue was erected in the city of Neapolis, probably due to some yet unknown connection between Ulpius and the city. Another statue found in Ankara describes the new honour that the synod

45. Translation by Harland $2014=$ http://philipharland.com/greco-roman-associations/honorarydecree-by-performers-for-ulpius-aelius-pompeianus-128129-ce/

46. Governor of Galatia: $P I R^{2} \mathrm{~T} 325$.

47. Petzl and Schwertheim, 2006, pp. 30-31 point out that Pompeianus achieves the citizenship under Trajan, although he uses the demonym/gentilic of Hadrian, surely because of his closeness to the latter.

48. IGR III, 209; SEG 6, 59; AE 1926, 73; Mitchell and French, 2012, n 141.

49. Mitchell and French, 2012, $n^{\circ} 139, n^{\circ} 142$ decree (id., $n^{\circ} 141$ ) is carved on one of the sides of the base of a statue, with another side including the dedication of the statue to Ulpius Pompeianus by the synod of technitai of Dionysos and of the emperor Trajan Hadrian Cesar Augustus (id. $\mathrm{n}^{\circ}$ 140). 
bestowed upon Ulpius Aelius Pompeianus. In this case, Torcuatus, the city Helladarcha, had the Synod erect two golden tondi with the image of Pompeianus which, as indicated in their inscriptions, had to be displayed in two of the most important points of the city. ${ }^{50}$ It is possible that one of the tondi is nowadays preserved in the Museum of Anatolian Civilizations in Ankara. Stephen Mitchell has identified another of the two effigies of Pompeianus as a bronze imago clipeata, usually attributed to Emperor Trajan. ${ }^{51}$

Ulpius Aelius Pompeianus, the first agonothetes of Ankara's mystikos agon, can be linked to the diffusion of this type of agon to other cities of Asia Minor. In lines 7-8, of the previously discussed second stele a mysteric celebration, this time

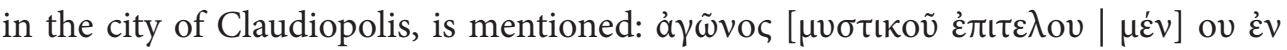

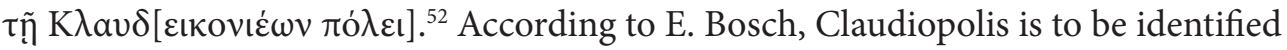
with Iconinum, current Konya, which changed its name during the reign of Emperor Claudius. The relationship of this city with the Emperor Hadrian is rather weak: the only attestation of it indicates that Hadrian granted to the city the status of Roman colony and renamed it as Adriana Augusta Iconensium. It is possible that due to the imperial concession, the city deemed it appropriate to carry out some kind of celebration to honour the Emperor Hadrian. The fact that the mystikos agon of Iconium is mentioned in the stele where the honours that the synod grants Ulpius Aelius Pompianus are listed could point to Pompeianus himself as the responsible for promotion of this kind of agon to a few other cities of Asia Minor.

Also in Side (Pamphylia) there is evidence of the organization of an agon mystikos dedicated to the emperor, Dionysus, and Demeter. ${ }^{53}$ While the evidence for these ceremonies is from a later period, and the only dated inscription belongs to Commodus' times, the relationship between Hadrian and the two deities suggests that the agon was probably introduced during Hadrian's time. ${ }^{54}$ S. Mitchell and D. French hypothesize that behind the foundation of the agon in Side was P. Aelius Pom-

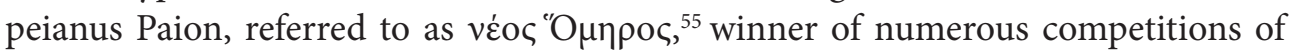
poetry, songwriter, rapsodos of the divine Hadrian, one of the leading members of the synod of the technitai in Hadrian's times, and responsible for the synod granting

50. IGR III, 210; SEG VI 58; Mitchell and French, 2012, p. 143.

51. Mitchell, 2014, pp. 1-10.

52. Reconstruction by Bosch, 1967, no 130.

53. Robert, 1960, 366; Nollé, 1986, p. 205.

54. I.Tral. 135; I.Side 149.

55. I.Side II 70.

ARYS, 16, 2018 [177-205] ISSN 1575-166x 
honours to Aelius Alcibiades. ${ }^{56} \mathrm{~S}$. Fein indicates that there is a connection between Pompeianus Paion and Ulpius Aelius Aelius Pompeianus of Ankara, and interprets Aelius Paion's choice of taking the cognomen Pompeianus as a way to display his cultural affinity with Ulpius Aelius Pompeianus. As pointed out by S. Mitchell and D. French, if this hypothesis is correct, it can surely "emphasize the importance of the latter as a leading personality in the artists' guild at this time, and explain the extraordinarily conspicuous honours that he received from its members". ${ }^{57}$

\section{The Hadrian Agonistic Calendar and the Greek Cities}

Epigraphic evidence shows that there was a close relationship between the emperor and the synod of the technitai..$^{58}$ It is likely that the foundation of mystikoi agones in those cities where there is no evidence of the organization of any other games dedicated to Hadrian, is to be seen as the will to honour the emperor as the patron and benefactor of the synod, that is, as the New Dionysus. The stele found in Alexandria Troas includes three letters dated $134 \mathrm{AD}$, signed by the Emperor Hadrian and addressed to

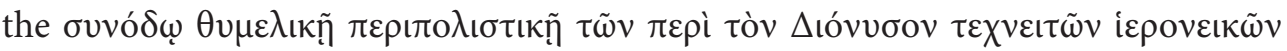
$\sigma \tau \varepsilon \varphi \alpha v \varepsilon \varepsilon \tau \tilde{\omega} v$ ("the travelling musical union of artists associated with Dionysus and victorious in sacred and crowned contest") which describe Hadrian's major reorganization of all the agones held across the Roman empire. In the first and third of these letters a number of rules applying to the games are established, for examples on how the games were to be funded, how to punish misdemeanours, the privilege of anaptosis or banquet offered to the winners of the various contests, and the details of ceremony by which they were to be granted cash prizes, if applicable. ${ }^{59}$

The second of the letters is the most interesting for the purpose of this article. In this one, the Emperor Hadrian organizes a calendar of the major agonistic games over a four-year cycle that began with the Olympics games, since they were "the oldest and most renown games in the Greek world" and ended with the Panhellenia games of Athens. Hadrian's agonistic calendar formed a new periodos or circuit that includes the most important games of the Roman Empire. Among them were obviously those games which constituted the archaia periodos (Olympia, Delphi, Isthmia and Nemea)

56. I.Eph. 22.

57. Fein, 1994, pp. 118-26; Mitchell and French, 2012, p. 308.

58. An edict found in Egypt states that the emperor favoured the association and granted to its members, among other things, juridical immunity and exemption from military service: Oliver, 1989, no 96 A-C.

59. Petzl and Schwertheim, 2006. 
and the three great Roman games of Nicopolis, Rome and Neapolis. Together with them there appear many civic games, which, by means of their integration into the nea periodos by the emperor, granted to their own cities a privileged status.

This could have be especially true in the case of the games dedicated to the Emperor Hadrian. Among the agones that constitute the Hadrianean circuit we do not find all of the agones dedicated to the emperor, but only some of them: the Hadrianeia of Smyrna, the Hadrianeia of Ephesus together with the Hadrianeia, the Olympia and the Panhellenia of Athens. By the integration of their games into the new calendar, the emperor had a powerful tool at his disposal for granting a privileged status to some Greek cities. It is possible that the emperor's decisions in this sense depended on the degree of closeness Hadrian had with the various city-elites, especially those who founded ceremonies dedicated to the emperor and even commemorated some of the most important events of his life and political career. To this end, a thorough analysis of the games would improve our insight and understanding of the reasons behind the emperor's choice to include specific games in his nea periodos, thus privileging specific cities.

\subsection{SMYRNA}

The Smyrna games are mentioned in lines 71-72 of the letters of Alexandria Troas where Hadrian established that they should begin on the 4th of January of the fourth Olympic year, that is, $137 \mathrm{AD}$ : "The Smyrnaeans shall begin their local Hadrianea ${ }^{60}$ from the day before the Nones of January and will hold the festival for forty days". ${ }^{61}$ The city of Smyrna oweed the celebration of the games dedicated to Hadrian to the sophist M. Antonius Polemo of Laodicea (Phrygia), who was based in Smyrna and had among his disciples Herod Atticus, as we know from inscriptions and Philostratos' works. ${ }^{62}$ His oratory skills earned the city of Smyrne an award of ten million drachmas from the emperor Hadrian, money that was used for the erection of a grain market, a temple and a gymnasion, the grandest of all Asia. ${ }^{63}$ The last two buildings are mentioned in a Smyrnean inscription, which can be dated to $124 \mathrm{AD}$ by means of the consulate of M.A. and C. Bellicus Glabrio Tebanius Torquatus. The inscription

60. Epigraphic sources also refer to them as Hadrianeia Olympia, Hadriana Olympia or Megala Hadriana Olympia: IGR IV 1431; I.Olymp. 237; FD III.1, 549, 550; FD III.6, 143; IG II², 3162; I.Tral. 118, 136; IG XIV, 1102; IG II-III, 3169/70; I.Eph. 1615, 1131; I.Smyrna II.1, 660, 661668.

61. Translation by Jones, 2007, p. 155.

62. In general on M. Antonio Polemon see Swain, 2007.

63. Philostr., VS 1, 25 (531).

ARYS, 16, 2018 [177-205] ISSN 1575-166X 
includes a list of 25 names of the people who had carried out some kind of euergesia, probably destined to the gymnasion. Lines 28-38 mention the euergesia which the Emperor Hadrian had accepted to carry out "through the help of Antonius Polemo". Among these euergesiai there is the second neokoria which was granted to the city before or in $124 \mathrm{AD}$ with the approval of the Senate, and the organization of the ceremonies associated with the imperial cult: payments to theologians and hymno$d o i ;{ }^{64}$ funds for the 92 columns for the gymnasion, 72 of marble from Synnada, 20 of Numidian marble and 6 of porphyry; and the celebration of a sacred agon, which represents a likely reference to the Hadrianeia games.

Polemon's closeness to the emperor and the benefits that he achieved for the city made so that Smyrna granted him and his heirs, among other honours, a lifelong agonothetia: "heaped on the head of Polemo all the wreaths of honour that were theirs to give, decreeing for himself and his family the distinctions most sought after in Smyrna; for they bestowed on him and his descendants the right to preside over the Olympic games founded by Hadrian, and to go on board the sacred trireme", a position which he held with great devotion. ${ }^{65}$

\subsection{EPHESUS}

Ephesus' games appear twice in the letters of Alexandria Troas. The first mention is in lines 45-47, which mention the process by which the games dedicated to Hadrian had been instituted: "I have also written to the councils of the provinces indicating that the Ephesians have distributed the categories in the Balbilleia between two contests, and that those who win the Hadrianeia there must receive the contributions as they received them when they won the Balbilleia. This has also been written to Petronius Mamertinus, my friend and the prefect of Egypt, so that there too payment is to be made to victors in the Hadrianeia of Ephesus" ${ }^{66}$ These lines describe how the contests which initially were part of the Balbilleia games were split into two different agones: the Balbilleia and the newly-created Hadrianeia. The Balbilleia included all kinds of contests, such as competitions of trumpeters and heralds, and athletic disciplines such as stadion, dolichos, pentathlon, pankration, boxing, wrestling and even rhetoric contests or musical ones such as the Pythian flute. ${ }^{67}$ Since the inscriptions that

64. About their function see Fontani, 2007, pp. 237-240.

65. Philostr. V S I 25 (534).

66. Translated by Jones, 2007, p. 154.

67. Lehner, 2004, pp. 177 and 179, $\mathrm{n}^{\circ} 4$. 
relate the winners of the Hadrianeia of Ephesus ${ }^{68}$ also include contests which were held in the Balbilleia, Y.-J. Strasser concludes that "il a été remarqué que ce partage des épreuves entre Balbilleia et Hadrianeia, si tel est le cas, n’a pas duré, puisque les mêmes spécialités sont connues pour l'un et l'autre concours" and that "les Balbilleia et les Hadrianeia tels qu'on les connaît dès la seconde moitié du II' $s$. ne peuvent être seulement le résultat du partage des épreuves en deux concours". ${ }^{69}$

There is a great deal of epigraphic evidence about the Hadrianeia games founded ex novo in Ephesus. ${ }^{70}$ We know the name of several of the agonothetai, such as Aristokrates of Ceramo, M. Fulvio Publicanus and M. Antonius Lollianus, with some of them even having been appointed for life such as Cn. Dottius or P. Vedius Papianus Antoninus. ${ }^{71}$ It is interesting to notice how all inscriptions, including the Cn. Dottius' one, refer to the games as Megala Hadrianeia. M.N. Tod rightly sees the megala as referring to the magnitude of the games themselves that the agonothetai are funding, and not to the imperial cult. ${ }^{72}$ Under this perspective, the games' titulature would be another tool for the competition among city-elites in their attempt to be remembered as great euergetai and maecenates of the polis.

The second mention of the Ephesian games in the letters of Alexandria Troad occurs at lines 69-70, where it is stated that: "The Ephesians shall leave an interval of four days from the shield(-race) in Pergamum and the contest shall be finished on the fortieth (day) from the beginning" ${ }^{73}$ Hadrian does not specify which Ephesian games are the ones inserted in the third Olympic year of his calendar, and the issue has been the subject of scientific debate. Scholars are split between two hypotheses, either that those were the games organized by the Koinon Asia, or that they were the Hadrianeia games. The editors of the letters of Alexandria Troas, G. Petzl and E. Schwertheim, together with L. Shear, opt for the games of the Koinon Asia to be placed in December-January of the third Olympic year. On the other hand, W.J. Slater and J.-Y. Strasser place the Hadrianeia of Ephesus games in June of the second Olympic year, while

\footnotetext{
68. Lämmer, 1967, pp. 53-55.

69. Strasser, 2010, p. 605, no 25.

70. Olymp 237; I.Anazarbus 25; CIL III 296; I.Eph. 724, 730, 618, 1083, 1085a, 1087a, 1132, 1153 1604, 2072, 4114; EA 1990, 34-36 = SEG 40, 1141; I.Tral. 117, 135; EA 1993, 131-133, pl. 16 = SEG 43, 731; IG XIV, 739, 1102, 1113; FD III.1, 550; IG II-III, 3169/70; IGR IV, 1432; IGR III, 370; CIG 2810, 5913; SNGD 1957ff, 1905; SNGR 1942 ff. 443. On the grammateus of the agon: Lämmer, 1967, p. 58.

71. I.Eph. 618, 724, 730, 1085a, 1087a, 1153.

72. Also megala in: Erytrea: IGR IV, 1542; Smyrna: I.Smyrna II.I, 661; Thyatira: SEG 49, 1703, I.Smyrna 668 and TAM V.2, $1026=$ IGR IV, 1260.

73. Translated by Jones, 2007, p. 155.
} 
P. Gouw inserts them in July of the 3rd Olympic year. The latest contribution to this problem has been by R. Gordillo, who inserts the Hadrianean games of Ephesus in December-January of the third Olympic year, thus linking the games to the celebration of the birthday of Emperor Hadrian.

\subsection{Athens}

Three Athenian games dedicated to the emperor, the Hadrianeia, the Olympia and the Panhellenia, are included in Hadrian's nea periodos. The first two games were entirely organized by the city, while the third one, although it takes place in Athens, was organized by the Panhellenion, a newly founded league of cities. Lines 62-63 of the letters of Alexandria Troas state that: "After the Olympia shall be the Isthmia, and after the Isthmia the Hadrianeia, so that the contest begins on the next day after the festival at Eleusis ends" ${ }^{74}$ As various scholars have pointed out, the fact the panegyris of Eleusis ${ }^{75}$ and the Hadrianeia were held in subsequent days indicates that Hadrianeia games had to be held in a location close to the Eleusinian sanctuary, probably Athens, since otherwise the athletes would not have the time to travel from one event to the other. Epigraphic evidence does not indicate the time of the foundation of the Hadrianeia. ${ }^{76}$ They are likely to have been found in 124/125 AD on occasion of the celebration of the first visit of Emperor Hadrian. Epigraphic evidence shows that in 124/125 AD the Athenian calendar started on the 1st of Boedromion, while previously it started on the 1st of Hecatombeon. ${ }^{77}$ According to O. Palagia, this alteration is due to Hadrian's plan to associate the figure of Augustus with the Athenian polis. Since 9/8 AD, the Asian cities followed a common calendar in which the new year began on the $23 \mathrm{rd}$ of September, Augustus' birth day. ${ }^{78}$ Palagia hypothesizes that Hadrian changed the beginning of the Athenian calendar to the month of Boedromion, thus following the Asian calendar, in order to promote the cult of Augustus in Athens. ${ }^{79}$ However, there are a number of problems with this interpretations. First, of all, Roman emperors did not usually get involved in changes to the provincial or

74. Translated by Jones, 2007, p. 155.

75. On the identification of Eleusis' contests see Le Guen, 2010, p. 213; Strasser, 2010, pp. 610-611.

76. FD III.4, 308; FD III.6, 143; CIG 3674; TAM II, 587; FD III.1, 89, 547, 549 A-D; BE 1970, 16; IG III 20; IG XIV, 739 = IGR I, 444; I.Eph. 2072; IG XIV, 1102; FD III.1, 550; IGR IV, 1761; I.Sardis VII 79; Robert, 1989, 647-668; I.Eph. 1112, 1131, 1613; IGR IV, 1432; FD III.1, 555.

77. Follet, 1976, p. 117.

78. OGI 458.

79. Palagia, 2008, p. 228. 
civic calendars. When Julius Caesar changed the official Roman, not all provinces and cities of the empire adopted the new calendar, as it was the case of Athens, which continued with their measurement system based on lunar time. Similarly, the aforementioned new calendar for Asia was the work of the "Greeks of the Province of Asia" who, urged by Paulus Fabius Maximus, proposed to change the day of the new year to the 23rd of September in order to express their gratitude to the emperor for his generosity toward them. If the Athenian citizens decided to change the calendar and make the new year begin on the 1st of Boedromion, their intention was probably to honour, rather than Augustus, the emperor Hadrian, whose words as related by an

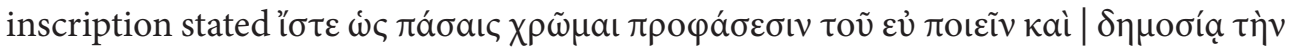

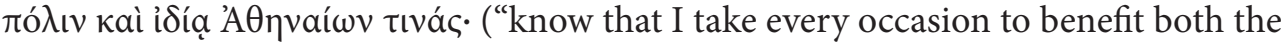
city publicly and any of the Athenians privately"). ${ }^{80}$

In the month of Boedromion the great Eleusinian Mysteries, the rituals to Demeter and Kore, took place in Eleusis. We know that Emperor Hadrian participated in them twice, in the year $124 \mathrm{AD}$ in order to achieve the rank of mystes, and in 128/129 AD in order to become epoptes. ${ }^{81}$ In coinage iconography his initiation is represented by the emperor wearing toga civilis and by the legend HADRIANUS AUGUSTUS PATER PATRIAE REN(atus), that is, he who has participated in the mysteries and was reborn. ${ }^{82}$

The new Athenian calendar year started on the 1st of Boedromion, thus coinciding with the start of ephebic year. The Hadrianeia games for the epheboi were probably founded in the same year as the Hadrianeia Panhellenic games, which were held every four years and enjoyed the participation of the most prestigious athletes of the empire. ${ }^{83}$ According to P. Graindor, the ephebic games were founded in 124/125 $\mathrm{AD}$ in connection with the changes to the Attic calendar, and were officialy held for the first time in $125 / 126 \mathrm{AD} .{ }^{84}$ It is possible that both games, the athletic and the ephebic, were created at the same time, in occasion of the first visit of Emperor Hadrian. Thus, if we take the new Hadrianeia periodos of Alexandria Troas as the frame of reference, the Hadrianeia games would have been held in November of the first Olympic year, i.e. 133 A.D. Therefore, this year would make it the third time that the

80. IG II ${ }^{2}, 1102$, 11. 10-11.Translated by Oliver, 1970, p. 216.

81. Aur. Vic., 14, 4; HA, Had. 13, 1; Galimberti, 2007, p. 131; Birley, 1997, p. 175.

82. Kuhlmann, 2002, p. 75.

83. IG III, 121, 1108, 1113, 1114, 1119, 1120a, 1121, 1122, 1123, 1124, 1128, 1129, 1133, 1138, 1146, 1147, 1160, 1162, 1168, 1169, 1171, 1173, 1177, 1185, 1188, 1192, 1193, 1197, 1202.

84. Graindor, 1922, p. 180. 
Hadrianeia were held, following their inauguration in $125 \mathrm{AD}$ and their celebration for the second time in $129 \mathrm{AD}$.

Other Athenian games that appear in the new Hadrianic periodos are the Olympia. ${ }^{85}$ Line 70 of the letter of Alexandria Troas states that "(The contestants shall go) to the Joint (Festival) of the Achaeans and Arcadians in Mantinea, and then to the Olympia. In this year the Panhellenia take place" ${ }^{86}$ As shown by J. Y. Strasser, the Olympia games referred to in this line are those that were held in Athens as they are referred to as 'O $\lambda \dot{v} \mu \pi \varepsilon \imath \alpha$, a term used together with 'O $\lambda \dot{v} \mu \pi \varepsilon i \tilde{\alpha}$ to designate the Athens Games, while the term 'O $\lambda \dot{u} \mu \pi \iota$ a was used for the Games of Olympia. ${ }^{87}$ In Athens Hadrian, among other things, financed the works of completion of the Olympieion, and epigraphic evidence shows that this euergesia was celebrated by the city who gave the emperor, among others, the title of Olympios in $128 / 129$ AD. It is likely that in that same year the city founded the Olympia games to honour the emperor's new title and his patronage of the city. ${ }^{88}$ The first celebration of the Olympia could have been carried out in $133 \mathrm{AD}$, as can be implied from the inscription of the auletes P. Elius Elianus. ${ }^{89}$

The letters of Alexandria Troas only state that the Panhellenia games, which closed the agonistic circuit, and the Athenian Olympia were held in the same year, without specifying the month. The inscriptions of some athletes represent the main evidence for the dating of the Olympia games. Line 25 of the inscription of M. Aurelio Asclepiades, a pancratiast of around 200 A.D., lists the games won by him in this

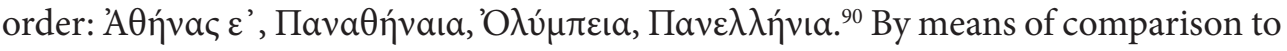
the order in which the other cities celebrations appear, it is likely that the distribution of Athenian games followed a chronological order within the Olympic circuit, first the Panathenaia, then the Olympia, and finally the Panhellenia. Thus, the Olympia would have taken place at some time between Panathenaia and Panhellenia. In the athletic inscription of an unknown pentathlete of Ephesus from the second half of the second century AD the order of the games mentioned after the Panathenaea games

85. IG V.1, 479; CIG 1068, 2810b, 2811b; TAM II 587; I.Tral. 117, 136; IG XIV 739, 1102, 1112; IG II ${ }^{2}$ 3161, 3162, 3303, 3687, 3966a, 4075; I.Sardis VII 79; FD III.1, 547, 549; Moretti, 1953, no 75; I.Eph. 1131; I.Smyrna II.1, 661.

86. Translated by Jones, 2007, p. 155.

87. Strasser, 2010, pp. 614-615.

88. Camia, 2011b, pp. 36-42. On the date see Graindor, 1934, p. 42; Follet, 1976, p. 346.

89. FD III.I 547; Luberto, 2018, p. 55.

90. IG XIV, 1102. 


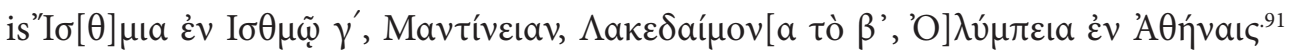
Unfortunately, the inscription does not specify which games were won in Mantinea by said pentathlete. However, the vast list of Aurelio M. Damas Demostratos indi-

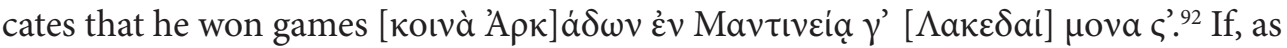
the inscription of Damas shows, the games held before the Spartan Games are to be identified with the games of the Koinon of the Arcadians in Mantinea, it is likely that the mention of Mantinea in the inscription of the unknown pentathlete actually refers to the koinon of the Arcadians itself. The Hadrianean calendar frequently establishes the temporal sequence Isthmia - Koinon Mantineans - Olympia of Athens. Thus, placing the games of Mantinea after the Isthmia games in the fourth Olympic year would mean that the Olympia games would have taken place just after the Koinon of Arcadians, probably around the Attic month of Posideon.

Epigraphic and literary sources provide no clear reason for choosing the month of Poseideon in order to celebrate the Olympia. However, epigraphic evidence shows that at some point after 124/125 AD the name of the Athenian intercalary month,

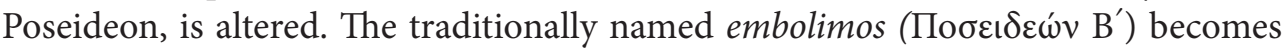

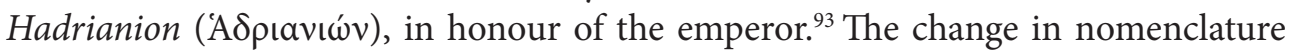
of the months in the provincial calendars as a way to honour the emperors was a common practice, either by means of the emperor's proper name, or with an epithet such as $\Sigma \varepsilon \beta a \sigma \tau$ tó or Kaıбapıoc. In Egypt, the month of Choiak (December) was renamed Adpıavóc, obviously with the aim of honouring the emperor. Scholars explain the change in the Egyptian nomenclature which was performed around $130 \mathrm{AD}$ as meant to commemorate the journey of Hadrian and his retinue across Egypt ${ }^{94}$ However, the studies by K. Scott on Egyptian epigraphy show that "the month Adplavó was in use as early as $119 / 120$ or perhaps in $118 / 119$ ". ${ }^{95}$ According to Scott, the only date that justifies the change in the nomenclature of the Choiak month is the 10th of December of $117 \mathrm{AD}$, the day when Hadrian received his second tribunicia potestas. Although the choice of the month Poseideon remains open to debate, it is possible to hypothesize that the Athenians followed the Egyptian example in choosing the month Poseideon $=$ Choiak $=$ December for celebrating the Emperor Hadrian. Therefore, the change of the name of the intercalary month and the celebration of the

91. Moretti, 1953, no 75.

92. I.Sardis VII 79.

93. Follet, 1976, p. 363.

94. Weber, 1907, p. 257; Birley, 1997, p. 252.

95. Scott, 1931, p. 261.

ARYS, 16, 2018 [177-205] ISSN 1575-166X 
Olympia games in the month of Poseideon could reflect the Eastern tradition, started by Egypt, of commemorating Hadrian receiving the tribunicia potestas in Rome.

Therefore, the city of Athens had two games that were under its own supervision. There is no epigraphic evidence that mentions the names of the agonothetai of the Hadrianeia games. S. Follet assumes on the basis of an inscription mentioning

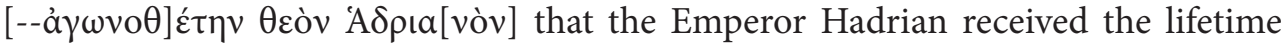
agonothesia of the games. ${ }^{96}$ However, there is no hard evidence for this hypothesis and for disclosing the identity of the heirs of the agonothesia after the death of the emperor. On the other hand, for the Olympia there is some epigraphic evidence of the names of some of the members of city-elite who received the agonothesiai: T. Flavio? (Hadrianean period), ${ }^{97}$ Elio Ardys (150/151 AD), Pomp. Hegias (3rd century AD) and Iulios Mousonios.

The agones that closed the Hadrianic nea periodos were the Panhellenia games of Athens: "after the Balbilleia (come) the Panhellenia and the Olympia following the Panhellenia" ${ }^{98}$ Probably the Panhellenian games ${ }^{99}$ were founded in 131/132 AD on occasion of the third and last voyage of the Emperor Hadrian to Athens, but they would not be actually held until after a few years later. During the visit to Athens, Hadrian presided over the inauguration of the temple of Zeus Olympios ${ }^{100}$ and the creation of a new supra-civic league, the Panhellenion. ${ }^{101}$ The league was a coalition of cities that had passed through a strict admission process, the main requisite being their ability to provide proof of their Greek ethnic identity. ${ }^{102}$ An example of this process is the attempt by city of Synnada to link its origins with Athens, as can be seen from the coin iconography, which displays not only hints at Synnada's origins as a Ionian colony, ${ }^{103}$ but also Athens' identifying attributes such as the goddess Ath-

96. Follet, 1976, p. 348.

97. Id. 250, 346.

98. Petzl and Schwertheim, 2006, 11. 72-73.

99. I.Olymp. 237; OGI 404, 3833; AE 1969, 30; AE 2001, 1826; IG III 17, 32, 129, 370, 681, 1141, 1199; TAM II 587; IG X 181; IG XIV 739, 1102; I.Sardis VII 79; IG IV 1474; IG II $^{2} 1106,3162,3163,3649 ;$ IG VII 49; SEG 34, 176; SEG 36, 258; I.Smyrna 661; I.Eph. 1131, 1613; Oliver, 1970, nn 19, 21; Follet, 1976, p. $345, \mathrm{n}^{\circ} 2$.

100. St. Byz., s.v. Olympieion; Philostr., VS I 25, 3 (533).

101. IG II ${ }^{2} 3289$; IG IV 1052. On the Panhellenion see Spawforth and Walker, 1985 and 1986; Gordillo, 2012; Corcella, Monaco and Nuzzo, 2013; Monaco, 2018.

102. Romeo, 2002, p. 21.

103. BMC PHRYGIA Synnada: $396 \mathrm{n}^{\circ} 23$. Dated around the time between Claudius' and Galienus' rule. The obverse shows a depiction of a bearded Thynnaros with the legend $\Sigma Y N N$ A $\triangle \mathrm{E} \Omega \mathrm{N}$. The reverse shows a Thyche with the legend $\mathrm{I} \Omega \mathrm{N} \Omega \mathrm{N}$. Another example appears in BMC PHRYGIA Synnada: 
ena Polias, ${ }^{104}$ the owl, and even the panathenaic amphorae that were granted to the winners of the Panathenaea contests. ${ }^{105}$ Stephanus of Byzantium, a sixth century AD writer, hints in his Ethnics at the issue of Synnada's origins by means of an allusion to the journey of Ionian Acamas, son of Theseus, who founded the city and populated him with Macedonians. ${ }^{106}$ In order to support its entry in the Panhellenion, Synnada began a campaign publicising its alleged Athenian ties, ${ }^{107}$ and founded the Panathenaia Hadrianea games, with the denomination Panathenaia providing a connection with Athens' own Panathenaia.

The complex organization of the Panhellenion League had its head in the Archon of the Panhellenion, together with an assistant, the antarchon. Underneath them were the panhellenes, the representatives of the cities that belonged to the Panhellenion. The functions of the league were political-administrative ones such as of seat of judicial proceedings, court of appeal, and representative body of its member cities before the imperial power; also religious ones, such as the organization of the

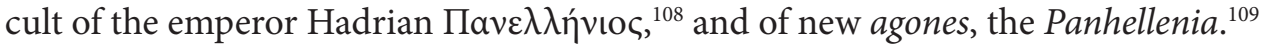

The Panhellenian games were managed by the Panhellenion League without any interference from Athens. Epigraphic sources indicate that the offices of Ar-

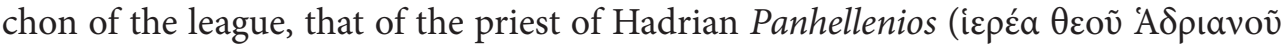

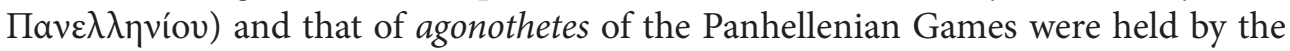
same person, ${ }^{110}$ so that the archon likely also supervised the league, the imperial cult

$396 \mathrm{n}^{\circ} 26$, with the legend $\Sigma Y \mathrm{NNA} \Delta \mathrm{E} \Omega \mathrm{NI} \Omega \mathrm{N} \Omega \mathrm{N}$. and the depiction of a conical mountain on the reverse. See also in the same catalogue other example at p. 405, n 67; p. 406, nn ${ }^{\circ} 70,71,73$.

104. RPC 8500, dated around the second century AD. On its obverse there is a Thyche wearing a towercrown with no legend. On the reverse there is Athena with her full attributes and the $\Sigma \Upsilon \mathrm{NNA} \triangle \mathrm{E} \Omega \mathrm{N}$, which represents a direct connection between the cities of Synnada and Athens

105. RPC 9999: dated around second century AD. The obverse shows a depiction of Thynnaros, with the legend $\Theta Y N N A P O \Sigma$. The reverse shows the Athenian owl and the commemorative amphoras which were given to the winners of the Panathenaic games.

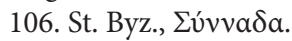

107. It is likely that the mind behind the propagandistic campaign was Tiberius Claudius Attalos Andragathos, who among other things was the eponym archon of Athens in 140/141 AD (IG II² 2047), panhellene of Synnada, strategos of the hoplites and priest of Dionysos Choreios, of Zeus Eleutherios (IG II $1075+2291 \mathrm{c}=$ SEG 30, 89 C, 16; IG V 45d2) and of the Homonoia of the Greeks in Platea $\left(I G \mathrm{II}^{2} 1105\right.$ = SEG 30, 86). In general on Tiberius Claudius Attalos see Nafissi, 1995.

108. IG II² 3626, 3386; IGR IV 552, 1157; SEG 39, 242; SEG 15, 530.

109. Cass. Dio LXIX 16, 2; Eusebii pamphili chronici canones, 260-282. This passage mentions the emperor's deeds in his sixteenth year of rule (132/133 AD). Follet, 1976, p. 348 links this passage with the Hadrianeia games, while according to Strasser, 2000, p. 569 it refers to the Panhellenia games.

110. Camia, 2011b, p. 45; Gordillo, 2012, pp. 69-73. 
and also the games associated with it, the Panhellenia. ${ }^{111}$ The election of a new archon among the panhellenes every four years allowed the cities of the Panhellenion, in spite of the fact that they did not organize their own games in honour of Hadrian, to show their devotion to the emperor by means of the Panhellenian games. The names of the archons who received also the agonothesiai: Herodes Attico (reign of Hadrian); Q. Elio Epicteto (reign of Hadrian-A. Pius); T. Flavio Cylo (153-157 AD); T. Elio Geminio Macedo (189-93 AD). ${ }^{112}$

\section{Conclusions}

Under the rule of Emperor Hadrian many cities organized agonistic games dedicated to the emperor. Hadrian's journeys to the Greek territories were likely the impulse behind the cities' attempts to honour the emperor by means of dedicating such games to him. To the emperor, the games represented an useful tool for spreading the imperial cult by means of Hellenic rituals that would be widely accepted across the Greek territories. On the other hand, the city-elites who organized the games used them as an opportunity to distinguish themselves and to obtain from the emperor titles and honours for both themselves and their city. But also supracivic entities such as the synods of athletes and technitai, with the latter being responsible for the founding of the mystikos agon dedicated to the emperor as New Dionysus in Ankara, Side and Iconium, were the recipients of the emperor's favour thanks to their connection to the games.

The analysis of agones held in honour of Hadrian also provides insight into the degree of closeness between civic elites and the emperor. Specifically, those cities that did not enjoy especially close ties with the emperor were the ones who tended to organize "Hadrianean games" more or less on their own initiative. For example, the cities of Thespiae and Xanthos, who already were holding games in honour of the emperor at least since the times of Trajan, simply included Hadrian's name in the titulature of their traditional games. On the other hand, a much stronger effort in seeking the emperor's favour than simply adding his name can be observed in those cities that founded "Hadrianean games" ex novo. The occasion of Hadrian's visits had many cities seeking funding to commemorate the arrival of the emperor, and the creation of una tantum agones such as those in Erytrea, Athens, Tebtynis,

111. IG II $^{2}$ 1093, 2243, 3626; IG IV 1474. IG X.2, 181; IGR IV 573 y 576. Philostr., VS 1, 3 y 2, 17; Camia, 2011a, p. 104.

112. Spawforth and Walker, 1985, pp. 84-85. 
Thyateira, Coela, Tralles, Gaza, Alexandria, Attuda, Bitinia-Claudiopolis, Magnesia ad Sipylum, Oenoanda and Sardis. Those cities which the emperor not only visited but granted titles or benefits to, create permanent agones that are documented to have been held until the third century AD, such as those in Heraclea, Anazarbus, Antioch, Tarsus or Cyzicus.

Hadrian included in his nea periodos only five agones entirely dedicated to the emperor himself. The cities that organized these agones, Ephesus, Smyrne and Athens acquired thus a privileged status compared to other cities whose "Hadrianean games" were not included in the nea periodos, and such inclusion is probably to be linked to the commemorations on behalf of these cities of great achievements of the emperor and important moments of his life. The games of Ephesus and Smyrna were held in January, which might be related to the celebration Hadrian's birth day; the Hadrianeia games of Athens were held in the month of Boedromion, which hints at their possible function of commemorating the emperor's "rebirth" after his initiation to the mysteries of Eleusis; and placing the Olympia in December would link them to the celebration of Hadrian's tribunicia potestas. Finally, the Panhellenia celebrated the founding of the Panhellenion League and the union of all Greeks under one koinon of imperial creation. 


\section{BibLIOGRAPHY}

Albanidis, E. and Giatsis, S. (2007). Athletic Games in Thrace during the Imperial Era. Nikephoros, 20, pp. 177-197.

Atkinson, K.M.T.Ch. (1949). Ancient Sparta: A Re-examination of the Evidence. Manchester: Manchester University Press.

Baker, P. and Thériault, G. (2014). La vie agonistique xanthienne: nouvel apport épigraphique (première partie). REG, 127.1, pp. 97-118.

Bérenger, A. and Perrin-Saminadayar, É. (2009). Les entrées royales et impériales: Histoire, représentation et diffusion d'une cérémonie publique, de l'Orient ancien à Byzance. Paris: De Boccard.

Birley, A. (1997). Hadrian: The Restless Emperor. London: Routledge.

Birley, A. (2004). Los viajes de Adriano. In Cortés Copete and Muñiz, 2004, pp. 59-69.

Boatwright, M.T. (2000). Hadrian and the Cities of the Roman Empire. Princeton, New Jersey, Oxford: Princeton University Press.

Bodnar, E.W. and Mitchell, Ch. (1976). Cyriacus of Ancona's journeys in the Propontis and the Northern Aegean 1444-1445. Philadelphia: American Philosophical Society.

Borg, B.E. (2004). Paideia: the world of the second sophistic. Berlin, New York: Walter de Gruyter.

Bosch, E. (1967). Quellen zur Geschichte der Stadt Ankara im Altertum. Ankara: Türk Tarih Kurumu Basimevi.

Boschung, D., Busch, A.W. and Versluys, M.J. (2015). Reinventing “The invention of tradition”: Indigenous Pasts and the Roman Present. Paderborn: Wilhelm Fink.

Bradford, A.S. (1977). A Prosopography of Lacedaemonians from the death of Alexander the Great, 323 B.C., to the sack of Sparta by Alaric, A.D. 396. Munich: C. H. Beck.

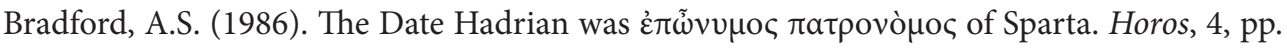
71-74.

Burrell, B. (2004). Neokoroi. Greek cities and Roman Emperors. Leiden and Boston:Brill.

Camia, F. (2011a). Spending on the agones. The financing of festivals in the cities of Roman Greece. Tyche, 26, pp. 41-76.

Camia, F. (2011b). THEOI SEBASTOI: Il culto degli imperatori romani in Grecia (provincia Achaia) nel secondo secolo D.C. Athens: Diffusion de Boccard.

Cartledge, P. and Spawforth, A. (2002). Hellenistic and Roman Sparta. London and New York: Routledge.

Corcella, A., Monaco, M.C. and Nuzzo, E. (2013). Ancora su Pausania I 18,9, la cd. Biblioteca di Adriano ed il Panellenio. ASAA, 91, Serie III.13, pp. 111-156.

Cordovana, O.D. and Galli, M. (2007). Arte e memoria culturale nell'età della Seconda Sofistica. Catania: Edizioni del Prisma.

Cortés Copete, J.M. and Muñiz, E. (2004). Adriano Augusto. Sevilla: Fundación José María Lara. 
Courtils, J. (2002). Xanthos et le Létôon. Rapport sur la campagne de 2001. Anatolia Antiqua, 10.1, pp. 297-333.

Downey, G. (1961). A history of Antioch in Syria: from Seleucus to the Arab conquest. Princeton: Princeton University Press.

Fein, S. (1994). Die Beziehungen der Kaiser Trajan und Hadrian zu den Literati. Stuttgart and Leipzig: Teubner.

Follet, S. (1976). Athènes au II ${ }^{\circ}$ et au $I I I^{\circ}$ siècle. Paris: Les Belles Lettres.

Fontani, E. (2007). La celebrazione dell' imperatore nelle feste in onore di Adriano nell'Oriente greco. In Cordovana and Galli, 2007, pp. 235-240.

Galimberti, A. (2007). Adriano e l'ideologia del principato. Roma: L'Erma di Bretschneider.

Gordillo, R. (2012). La construcción religiosa de la Hélade imperial: El Panhelenion. Firenze: Firenze University Press.

Graindor, P. (1922). Études sur l'éphébie attique sous l'Empire. Musée Belge, 26, pp. 165-228.

Graindor, P. (1934). Athènes sous Hadrien. El Cairo: Imprimerie Nationale.

Grelle, F. (1972). L'autonomia cittadina fra Traiano e Adriano: teoria e prassi dell'organizzazione municipale. Naples: Edizioni Scientifiche Italiane.

Haensch, R. (2009). L'entrée par la mer dans l'Antiquité. In Bérenger and Perrin-Saminadayar, 2009, pp. 91-99.

Halfmann, H. (1996). Itinera principum. Geschichte und Typologie der Kaiserreisen im römischen Reich. Stuttgart: F. Steiner Verlag Wiesbaden.

Hansen, E. and Le Roy, Chr. (2012). Le Temple de Létoon de Xanthos: Études architecturale. Paris: Editions Klincksieck.

Harland, Ph.A. (2014). Greco-Roman associations II, North Coast of the Black Sea, Asia Minor texts, translations, and commentary. Berlin: De Gruyter.

Hasluck, F.W. (1910). Cyzicus. Cambridge.

Højte, J.M. (2000). Imperial Visits as Occasion for the Erection of Portrait Statues?. Zeitschrift für Papyrologie und Epigraphik, 133, pp. 221-235.

Jones, A.H.M. (1998). Cities of the Eastern Roman Provinces. New York: Oxford University Press.

Jones, Chr. (2007). Three New Letters of the Emperor Hadrian. Zeitschrift für Papyrologie und Epigraphik, 161, pp. 145-156.

Kennell, N.M. (1991). The Size of the Spartan Patronomate. Zeitschrift für Papyrologie und Epigraphik, 85, pp. 131-137.

Kuhlmann, P. (2002). Religion und Erinnerung: Die Religionspolitik Kaiser Hadrian und ihre Rezeption in der antiken Literatur. Göttingen: Vandenhoeck und Ruprecht.

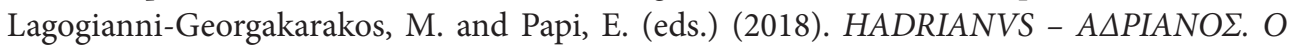

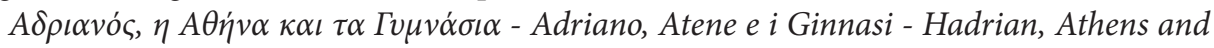
the Gymnasia. Athens: National Archaeological Museum / Scuola Archeologica Italiana di Atene.

Lämmer, M. (1967). Olympien und Hadrianeen im antiken Ephesos (dis.). Köln. 
Le Glay, M. (1976). Hadrien et l'Asklépieion de Pergamo. Bulletin de Correspondance Hellénique, 100.1, pp. 347-372.

Le Guen, B. (2010). Hadrien, l'Empereur philhellène, et la vie agonistique de son temps. À propos d'un livre récent: Hadrian und die dionysischen Künstler. Drei in Alexandria Troas neugefundene Briefe des Kaisers and die Künstler-Vereinigung. Nikephoros, 23, pp. 205-239.

Lehner, M. F. (2004). Die Agonistik im Ephesos der römischen Kaiserzeit (dis.). Munich.

Leschor, W. (1998). Die Verbreitung von Agonen in den östlichen Provinzen des Römischen Reiches. Stadion, 24, pp. 31-58.

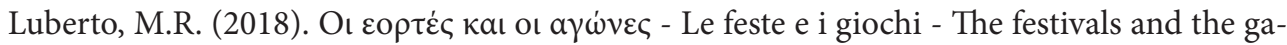
mes. In Lagogianni-Georgakarakos and Papi, 2018, pp. 54-57.

Magie, D. (1950). Roman Rule in Asia Minor. To the End of the Third Century after Christ. Princeton: Princeton University Press.

Mitchell, St. (1990). Festivals, Games and Civic Life in Roman Asia Minor. Journal of Roman Studies, 80, pp. 183-193.

Mitchell, St. (1993). Anatolia: Land, Men and Gods in Asia Minor, Vol. 1, Oxford: Clarendon Press.

Mitchell, St. and French, D. (2012). The Greek and Latin Inscriptions of Ankara (Ancyra). Vol. 1: From Augustus to the end of the Third Century AD. Munich: C.H. Beck.

Mitchell, St. (2014). The Trajanic Tondo from Roman Ankara. In Search of the Identity of a Roman Masterpiece. Journal of Ankara Studies, 2.1, pp. 1-10.

Monaco, M.C. (2018). To Пavع $\lambda \lambda$ ńvı Georgakarakos and Papi, 2018, pp. 50-52.

Moretti, L. (1953). Iscrizioni Agonistiche Greche. Roma: A. Signorelli.

Nafissi, M. (1995). Tiberius Claudius Attalos Andragathos e le origini di Synnada. I cultu plataici di Zeus Eleutherios e della homonoia ton Hellenon ed il Panhellenion. Ostraka, 4.1, pp. 119-136.

Nollé, J. (1986). Pamphylische Studien. Chiron, 16, pp. 199-212.

Oliver, J.H. (1970). Marcus Aurelius: aspects of civic and cultural policy in the east. Princeton and New Jersey: American School of Classical Studies at Athens.

Oliver, J.H. (1989). Greek constitutions of early roman emperors from inscriptions and papyri. Philadelphia: American Philosophical Society.

Palagia, O. (2008). The date and iconography of the calendar frieze on the Little Metropolis, Athens. Jahrbuch des Deutschen Archaologischen Instituts, 123, pp. 215-238.

Pavlogiannis, Onoufrios et alii (2009). The Aktia of Nikopolis: New Approaches. Nikephoros, 22 , pp. 79-102.

Petzl, G. (1974). Kleine Beiträge zu griechischen Inschriften aus Smyrna. Zeitschrift für Papyrologie und Epigraphik, 13, pp. 117-126.

Petzl, G. and Schwertheim, E. (2006). Hadrian und die Dionysischen Künstler: Drei in Alexandria Troas neugefundene Briefe des Kaisers an die Künstler-Vereinigung. Bonn: Habelt. 
Pleket, H. W. (1965). An Aspect of the Emperor Cult: Imperial Mysteries. The Harvard Theological Review, 58.4, pp. 331-347.

Pleket, H.W. (2010). Roman Emperors and Greek Athletes. Nikephoros, 23, pp. 175-203.

Robert, L. (1960). Hellenica. Recueil d'épigraphie, de numismatique et d'antiquités grecques. Vol. 11-12. Paris.

Robert, L. (1989). Opera minora selecta. Vol. 5. Amsterdam.

Robert, J. and Robert, L. (1978). Hadrien Zeus Kynégésios. Bulletin de Correspondance Hellénique, 102, pp. 437-452.

Romeo, I. (2002). The Panhellenion and Ethnic Identity in Hadrianic Greece. CPh, 97, pp. 21-40.

Schachter, A. (1981-1994). Cults of Boiotia. London: University of London of Classical Studies.

Scott, K. (1931). The Honorific Months in Greek and Roman Calendars. Yale Classical Studies, 2, pp. 201-277.

Spawforth, A.J. and Walker, S. (1985). The World of the Panhellenion I: Athens and Eleusis. Journal of Roman Studies, 75, pp. 78-104.

Spawforth, A.J. and Walker, S. (1986). The World of the Panhellenion II: Three Dorian Cities. Journal of Roman Studies, 76, pp. 88-105.

Strasser, J.Y. (2000). Les Concours grecs d'Octave Auguste aux invasions barbares de 3ème siècle: Recherches sur la date et la pèriodicité des concours sacrès (dis). Paris.

Strasser, J.Y. (2010). “Qu'on fouette les concurrents....”: à propos des lettres d' Hadrien retrouvées à Alexandrie de Troade. REG, 123.2, pp. 582-622.

Syme, R. (1988). Journeys of Hadrian. Zeitschrift für Papyrologie und Epigraphik, 73, pp. 159170.

Swain, S. (2007). Seeing the face. Seeing the soul. Oxford: Oxford University Press.

Van Nijf, O. (1999). Athletics festivals and Greek identity in the Roman East. Proceedings of the Cambridge Philological Society, 45, pp. 176-200.

Van Nijf, O. (2004). Athletics and paideia: Festivals and physical education in the world of the second sophistic. In Borg, 2004, pp. 203-227.

Van Nijf, O. and Williamson, Chr.G. (2015). Inventing Traditions in Greece, Rome and the Roman East. In Boschung, Busch and Versluys, 2015, pp. 95-112.

Wallner, Chr. (2001). Zur Agonistik von Gaza. Zeitschrift für Papyrologie und Epigraphik, 135, pp. 125-135.

Weber, W. (1907). Untersuchungen zur Geschichte des Kaisers Hadrianus. Leipzig: Teubner.

Weiss, Z. (2014). Public Spectacles in Roman and Late Antique Palestine. Cambridge and London: Harvard University Press.

Wörrle, M. (1988). Stadt und Fest im kaiserzeitlichen Kleinasien: Studien zu einer agonistischen Stiftung aus Oenoanda. Munich: C. H. Beck.

Ziegler, R. (1985). Städtisches Prestige und kaiserliche Politik: Studien zum Festwesen in Ostkilien im 2. und 3. Jahrhundert n. Chr. Düsseldorf: Schwann. 
Ziegler, R. (1993). Kaiser, Heer und städtisches Geld: Die Münzen von Anazarbos. Wien: Verlag der Österreichischen Akademie der Wissenschaften.

Zuiderhoek, A. (2009). The Politics of Munificence in the Roman Empire: Citizens, Elites and Benefactors in Asia Minor. Cambridge: Cambridge University Press. 